\title{
Insecticidal paint and fumigant canisters for Chagas' disease control: community acceptance in Honduras
}

\author{
Gustavo Adolfo Ávila Montes, ${ }^{1}$ Carlos Ponce, ${ }^{2}$ Elisa Ponce, ${ }^{2}$ \\ Mercedes Martínez Hernández, ${ }^{3}$ and Mario Flores ${ }^{4}$
}

\begin{abstract}
This study assessed public acceptance for two new vectorial control techniques for Chagas' disease: insecticidal paint and fumigant canisters. The study compared the two with traditional fenitrothion insecticide spraying. An experimental field study was performed in an endemic area of central Honduras from August to November 1992, a year after the initial application of the treatments.

The objectives of the study were to determine the acceptability of the tools on the part of the population whose homes were treated, and on the part of the personnel applying the treatments. The sample size was drawn up according to a uniform protocol applied in six Latin American countries. For this study a total of 651 persons were surveyed in 15 rural communities. Along with the surveys, focus groups were used to collect information to learn the reasons for accepting or rejecting particular treatments. The survey was done with heads of households. Focus groups were done with heads of households and also with the field operators who applied the treatments.

The research showed that insecticidal paint had a low level of community acceptance $(28.8 \%)$. Field operators strongly disliked the paint because of problems with its transport, application, unpleasant smell, and very low effectiveness against triatomines and pest insects. The traditional insecticide was more acceptable to the community (93.9\%) and to the field operators, especially for its strong effect against the triatomines and pest insects. The results showed that in order to increase the public acceptance for insecticidal paint, it would be necessary to make the paint easier to transport and apply and to increase its effectiveness. Because of their very low effectiveness, fumigant canisters did not represent an acceptable alternative for triatomine vector control. A public educational effort should be a component of any new control method developed.
\end{abstract}

Chagas' disease is a serious public health problem in Latin America. The

1 Pan American Health Organization, Tegucigalpa, Honduras. Address correspondence to: Gustavo Ávila Montes. Telephone: (504) 221-3721; e-mail: samat@hondudata.com

2 Ministry of Health, Central Laboratory, Tegucigalpa, Honduras.

3 Ministry of Health, Vector Borne Disease Department, Tegucigalpa, Honduras.

4 Ministry of Health, Planning Department, Tegucigalpa, Honduras.
World Health Organization (WHO) estimates that in Latin America at least 90 million people ( $25 \%$ of the population) are at risk of contracting the infection and that 16-18 million are already infected (1-5). These figures would indicate around 500000 new infections occur each year in the absence of successful control efforts (6).

The estimated number of disability adjusted life years lost due to Chagas' disease is 2740000 per year (7). That puts the global burden of Chagas in third place, after malaria and schistosomiasis. In Latin America, however, Chagas' disease ranks in first place among tropical diseases $(7,8)$.

In Honduras, triatomine vectors have been found in 17 out of 18 departments, with the highest seropositivity levels found in the western, eastern, and central zones of the country $(1,9)$. 
It has been estimated that the infected population numbers around 300000 . Of these, some 75000 people may have already developed chronic complications that should be treated with inpatient hospital services (10). Recent studies have shown that the prevalence of chagasic heart disease in endemic areas is as high as $10 \%$ (11). There are few options for Chagas control. There is no effective chemotherapy to treat infected patients, nor is there a vaccine for Chagas' disease or any prospect for one in the near future (12). Fortunately, traditional vector control methods based on insecticide spraying have been highly effective, and this approach is technically capable of controlling the domiciliary population of triatomines, according to experiences in Brazil and other countries (13-15).

Newer approaches to Chagas' disease vector control have also been tried. They include having householders use fumigant canisters and having spray teams use latex-base insecticidal paints. These methods have been proved to be effective not only in reducing vector densities but also in reducing or interrupting domestic transmission and the incidence of infection in countries that include Argentina and Brazil (16-19). Housing improvement programs have also shown good results ${ }^{5}$, and they have the advantage of promoting community participation and also improving the living standards of the population (20-23).

During 1991 and 1992 a multicenter research protocol testing the impact, cost, and community acceptance of these new vector control tools was launched in selected areas of Argentina, Bolivia, Chile, Honduras, Paraguay, and Uruguay. The respective national control programs carried out extensive field projects. Technical support came from the Pan American Health Organization (PAHO), the

\footnotetext{
5 Arata A. Participación comunitaria en el control de vectores peridomésticos de la enfermedad de Chagas. Tercer Taller Interregional sobre la Promoción del Ordenamiento del Medio Ambiente para el Control de Vectores a través de la Extensión Agrícola. Tegucigalpa, 13-17 October 1992.
}

WHO Division of Control of Tropical Diseases (CTD), and the Special Programme for Research and Training in Tropical Diseases (TDR), which is cosponsored by the United Nations Development Program (UNDP), the World Bank, and WHO (12, 24, 25). This article reports on the research in Honduras, which had the following objectives: a) determine the acceptability of the new tools to the population whose homes received treatment, $b$ ) determine the acceptability on the part of the personnel applying the new tools, and c) identify the reasons for the acceptance or rejection of particular treatments. This research would also indicate how these tools should be improved in order for the Ministry of Health to consider them for vector control operations.

\section{MATERIAL AND METHODS}

\section{Study area}

The study sites were 15 randomly chosen localities in central Honduras where the vector was present. The communities were in the municipalities of Cedros, Valle de Angeles, and Santa Lucia, in the department of Francisco Morazán, and ranged in altitude from 1000 to 1200 meters above sea level. The communities belonged to Health Region I of Honduras.

Based on epidemiological research, the communities were assigned to two study areas, Area A and Area B (Figure 1). Area A was infested mainly with Rhodnius prolixus and was found to have a house infestation index (HII) of $35.0 \%$ and a seropositivity index of $40.2 \%$. Area B was infested only with Triatoma dimidiata and had an HII of $53.1 \%$ and a seropositivity index of $27.8 \%$. The majority of the population in the communities was earning a living from agriculture, with an average daily income of 10.9 lempiras (US\$2.02 at the 1992 mean currency exchange rate).

Preliminary work included performing a detailed census of the chosen areas and creating maps where households were identified and enumerated for use in a sampling frame.
Entomological and cost-analysis studies were also carried out because there was a strong possibility that all the study measures were equally highly effective. The results of these studies can be found elsewhere (26-28).

Out of 750 persons whose homes had received an insecticide application between July and September 1991, 651 $(86.8 \%)$ were interviewed a year later, using survey questionnaires. No one declined to answer the questionnaire, but 99 of the people (13.2\%) could not be located because they had left to look for seasonal work in the coffee harvest. A team of experienced surveyors, made up of primary school teachers, received 2 days of training in data collection techniques before carrying out the data-gathering phase. A coded questionnaire was used and pretested at the field level. Along with the surveys, focus groups were used to collect information to learn the reasons for accepting or rejecting particular treatments.

\section{Experimental groups}

This Honduras research used the same standard research protocol as the five other countries in the multicenter study, but with adaptations for local linguistic idiosyncrasies. As in the other countries, experimental groups were set up in Honduras to test different combinations of the control interventions in and near the house and to compare them with applications of the traditional insecticide both in and near the house. Table 1 shows the groups, as well the number of homes initially treated and the number of households interviewed at the end of the year. (It is important to explain the apparent increase by 13 in the size of the first group of households, where insecticidal paint was used both inside and near the house. At the time of the evaluation visit, 12 months after the initial treatment, the field surveyors shifted 17 houses from the second group (insecticidal paint in the house plus traditional insecticide near the house) to the first group because of the destruction of the attach- 
FIGURE 1. Map of the department of Francisco Morazán showing the two study areas (smaller map indicates the location of the department within Honduras), Honduras, 1991-1992

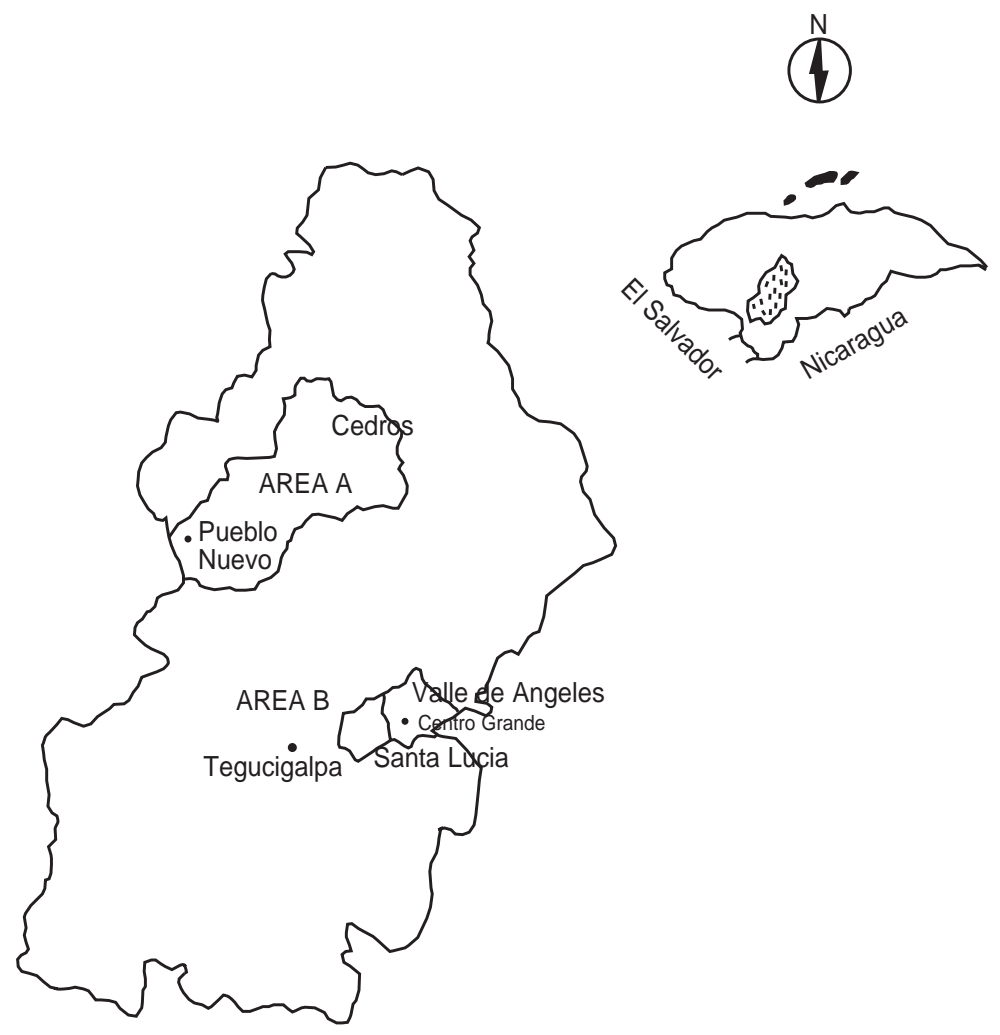

ments near the house (latrines and chicken coops) where the traditional insecticide had been applied.)

\section{The surveys}

The surveys were conducted in August and September 1992 in Area A

and Area B. Two versions of the survey questionnaire were used. One was used with the head of the household or that person's spouse, and the other was used with the field operators in charge of applying the treatments. However, since there were only 12 field operators, this study only presents the results of the household sur-

TABLE 1. Experimental groups for various triatomine control treatments, Honduras, 1991-1992

\begin{tabular}{|c|c|c|c|}
\hline \multicolumn{2}{|c|}{ Treatment } & \multirow{2}{*}{$\begin{array}{c}\text { Number of } \\
\text { houses treated }\end{array}$} & \multirow{2}{*}{$\begin{array}{l}\text { Number of } \\
\text { households } \\
\text { interviewed at } \\
\text { end of the year }\end{array}$} \\
\hline Inside the house & Near the house & & \\
\hline Insecticidal paint & Insecticidal paint & $150^{\mathrm{a}}$ & $163^{a}$ \\
\hline Insecticidal paint & Traditional insecticide & $150^{\mathrm{a}}$ & 96 \\
\hline Fumigant canister & Traditional insecticide & 150 & 129 \\
\hline Traditional insecticide & Traditional insecticide & 300 & 263 \\
\hline Total & & 750 & 651 \\
\hline
\end{tabular}

${ }^{a}$ At the time of the evaluation visit a year after the initial treatment, the field surveyors shifted 17 houses from the second group (insecticidal paint inside the house plus traditional insecticide near the house) to the first group (insecticidal paint plus insecticidal paint) because of the destruction of attachments (latrines and chicken coops) where traditional insecticide had been applied near those 17 houses.

veys. (For the field operators, results from focus groups are given below.)

For the household surveys, individuals were interviewed using a 13question semistructured questionnaire. The surveys asked about the health effects that the insecticide had on humans and on domestic animals found near the home, such as chickens, ducks, and dogs; the effectiveness of the insecticide; the effects on triatomines and domestic pests; and the insecticide's acceptability to the community.

For quality control with the surveys, several steps were taken. Each questionnaire was manually reviewed after an interview and before data entry. Approximately one-fourth of the questionnaires were selected and verified against data files to ensure accurate data entry. Frequencies were run and checked against coding instructions to identify possible errors. Crosstabulations were run on related variables to check for consistent and logical coding.

\section{Focus groups}

Four focus groups were conducted in Areas A and B, during September and October 1992. Each of the groups contained 10 to 12 persons whose homes had received an insecticide application. The objective was to build on the information from the survey questionnaires and gain more in-depth understanding of the reasons that these persons accepted or rejected the various insecticide treatments. This investigation was directed according to the guidelines established by Scrimshaw and Hurtado (29) and was guided by the principal investigator and a social worker participating as a co-investigator.

In addition, one focus group was carried out in November 1992, in Area $B$, with the two teams of field operators (comprised of six persons each) responsible for the insecticide applications. A discussion guide was developed covering operators' reasons for accepting or rejecting the new treatments, such as their effectiveness, side effects they caused, and ease or difficulty of application. The principal in- 
vestigator and the social worker led the focus group discussion with the field operators.

\section{Equipment and interventions}

Spraying was used to apply the insecticidal paint, which contained malathion mixed with polyvinyl acetate for use as a slow-release emulsion paint. The paint (Long Action $\mathrm{M}-10^{\circledR}$ ) has a residual effect of two years, according to the manufacturer, the Núcleo de Pesquisas de Produtos Naturais, Universidade Federal do Rio de Janeiro, Brazil $(16,17)$.

The fumigant canister produced a gas composed of various synergistic elements, among which diclorvos is the main insecticidal component (Agufog ${ }^{\circledR}$, VGA Laboratorios S.A., Buenos Aires, Argentina). The canister treatment does not have any residual effect $(19,30)$.

The traditional insecticide used was an organophosphate, fenitrothion, which has a residual effect for three months. The insecticide spraying was done with 10-liter X-Pert model sprayers (H.D. Hudson, Chicago, IL, United States of America), fitted with Teejet 8002 nozzles (Spraying Systems
Company, Wheaton, IL, United States of America).

\section{Statistical analysis}

The data were analyzed using the Epi Info 5.0 statistical program (U.S. Centers for Disease Control and Prevention, Atlanta, GA). Besides the descriptive statistical methods, this study also applied Kruskal-Wallis one-way analysis of variance (ANOVA); chisquare analysis $\mathrm{x}^{2}$ (Yates correction) applied to 2 by 2 contingency tables; and odds ratio with $95 \%$ confidence intervals, using the traditional insecticide as a reference. All results referred to as significant have a $P$ value of less than 0.05 .

\section{RESULTS}

\section{Intervention effectiveness}

Two hundred and fifty-five people who had reported the presence of triatomines in their houses before the insecticide application were asked how effective the various application methods were in eliminating the bugs. The traditional insecticide was considered effective by $97.2 \%$ of the people whose homes received that treatment both inside and nearby (Table 2). Only 57.6\% of the participants whose homes received the insecticidal paint treatment both in and near the home considered it effective. Two other combinations were deemed even less effective, paint inside the home with traditional insecticide applied near it $(50.0 \%)$ and fumigant canisters in the house and traditional insecticide near the home $(42.3 \%)$. According to the chi-square test of association $\left(x^{2}=66.5\right.$ for the first set of variables and $x^{2}=27.7$ for the second set), at the 0.05 significance level, we conclude that the type of control measure and the population's perception of effectiveness are associated.

The dual application of the traditional insecticide kept the homes free of triatomines for the following year, $81.7 \%$ of the residents in that group said in the survey (Table 2). Less effective, according to respondents in the other experimental groups, were the approaches of paint inside the home plus traditional insecticide applied near it $(75.0 \%)$, insecticidal paint both in and near the home $(68.7 \%)$, and fumigant canisters in the house and traditional insecticide near the home $(57.4 \%)$.

TABLE 2. Effectiveness of triatomine control measures as perceived by studied population, Honduras, 1991-1992

\begin{tabular}{|c|c|c|c|c|c|c|c|c|c|c|}
\hline \multirow[b]{3}{*}{ Treatment effectiveness } & \multicolumn{8}{|c|}{ Triatomine control measure } & \multirow[b]{3}{*}{$x^{2 b}$} & \multirow[b]{3}{*}{$P$ value } \\
\hline & \multicolumn{2}{|c|}{ Paint + paint } & \multicolumn{2}{|c|}{$\begin{array}{l}\text { Paint }+ \text { traditional } \\
\text { insecticide }\end{array}$} & \multicolumn{2}{|c|}{$\begin{array}{c}\text { Fumigant } \\
\text { canister + } \\
\text { traditional } \\
\text { insecticide }\end{array}$} & \multicolumn{2}{|c|}{$\begin{array}{c}\text { Traditional } \\
\text { insecticide + } \\
\text { traditional } \\
\text { insecticide }\end{array}$} & & \\
\hline & No. & $\%$ & No. & $\%$ & No. & $\%$ & No. & $\%$ & & \\
\hline \multicolumn{11}{|l|}{$\begin{array}{l}\text { Initial elimination of } \\
\text { triatomines }^{c}\end{array}$} \\
\hline Effective & 34 & 57.6 & 19 & 50.0 & 22 & 42.3 & 103 & 97.2 & 66.5 & $<0.0001$ \\
\hline Not effective & 25 & 42.4 & 19 & 50.0 & 30 & 57.7 & 3 & 2.8 & & \\
\hline \multicolumn{11}{|l|}{$\begin{array}{l}\text { Reinfestation of household } \\
\text { with triatomines during } \\
\text { first yeard }^{\text {dir. }}\end{array}$} \\
\hline Yes & 51 & 31.3 & 24 & 25.0 & 55 & 42.6 & 48 & 18.3 & 27.7 & $<0.0001$ \\
\hline No & 112 & 68.7 & 72 & 75.0 & 74 & 57.4 & 215 & 81.7 & & \\
\hline
\end{tabular}


To assess the strength of association between the type of measures and the reinfestation of households as perceived by study subjects, the odds ratios and their $95 \%$ confidence intervals were also calculated. The traditional insecticide was used as the reference group $(\mathrm{OR}=1)$. The probability of reinfestation was considerably higher when canisters were used $(\mathrm{OR}=3.3$; 95\% CI: 2.0-5.4) and somewhat higher when insecticidal paint was used both in and near the house (OR $=2.0 ; 95 \%$ CI: 1.2-3.3). No statistical difference was observed between the dual application of traditional insecticide and the approach of paint inside the house plus traditional insecticide near the house.

Table 3 shows the effect of the various approaches on domestic pests, as reported by the households in the different experimental groups. Traditional insecticide applied both in and near the house was effective, according to $96.0 \%$ of the householders. The lowest reported effectiveness occurred with the combination of paint plus traditional insecticide (57.3\%) and with the dual application of paint (57.8\%). In the middle was the use of canisters in the house and traditional insecticide near the house $(65.9 \%)$. According to the chi-square test there was an association between the type of triatomine control measures and the perceived effectiveness in the control of domestic pests. The domestic pests over which the insecticide had an effect included cockroaches, flies, bedbugs, lice, ants, mice and, in lesser proportions, mosquitoes, fleas, and spiders.

\section{Acceptability of the interventions}

Community surveys. To determine the acceptability of the treatment methods, two survey questions were asked. One question asked about the people's willingness to have a second treatment of the same type. The second question asked which alternative treatment method householders would prefer if they did not want to have the initial approach repeated.

Among the group of households where traditional insecticide had been applied both inside and nearby the house, $93.9 \%$ of those persons said they would like a second application for their homes (Table 4). A repetition of the fumigant canister application inside the house was preferred by $41.9 \%$ of the persons in that experimental group. A smaller share of the respondents in the other two groups wanted a repetition, $34.4 \%$ of those in the paint/traditional insecticide group and $28.8 \%$ of those in the group whose homes had received insecticidal paint both inside and nearby.

Among the persons whose homes had been treated on the inside with either insecticidal paint or fumigant canisters and who rejected a potential sec-

TABLE 3. Effectiveness of triatomine control measures on domestic pests as perceived by studied population, Honduras, 1991-1992

\begin{tabular}{|c|c|c|c|c|c|c|c|c|c|c|}
\hline \multirow[b]{3}{*}{ Effectiveness $^{b}$} & \multicolumn{8}{|c|}{ Triatomine control measure ${ }^{a}$} & \multirow[b]{3}{*}{$x^{2 c}$} & \multirow[b]{3}{*}{$P$ value } \\
\hline & \multicolumn{2}{|c|}{ Paint + paint } & \multicolumn{2}{|c|}{$\begin{array}{c}\text { Paint }+ \text { traditional } \\
\text { insecticide }\end{array}$} & \multicolumn{2}{|c|}{$\begin{array}{c}\text { Fumigant } \\
\text { canister + } \\
\text { traditional } \\
\text { insecticide }\end{array}$} & \multicolumn{2}{|c|}{$\begin{array}{c}\text { Traditional } \\
\text { insecticide + } \\
\text { traditional } \\
\text { insecticide }\end{array}$} & & \\
\hline & No. & $\%$ & No. & $\%$ & No. & $\%$ & No. & $\%$ & & \\
\hline Yes & 93 & 57.8 & 55 & 57.3 & 85 & 65.9 & 248 & 96.0 & 107.7 & $<0.0001$ \\
\hline No & 68 & 42.2 & 41 & 42.7 & 44 & 34.1 & 10 & 4.0 & & \\
\hline
\end{tabular}

a Treatment combinations are indicated for treatment inside the house and near the house, respectively.

${ }^{\mathrm{b}} n=644$.

${ }^{c}$ Kruskal-Wallis test.

TABLE 4. Willingness to receive a second application of the same triatomine control treatment, Honduras, 1991-1992

\begin{tabular}{|c|c|c|c|c|c|c|c|c|c|c|}
\hline \multirow{3}{*}{$\begin{array}{l}\text { Willing to receive the } \\
\text { same treatment }{ }^{\mathrm{b}}\end{array}$} & \multicolumn{8}{|c|}{ Triatomine control measure ${ }^{a}$} & \multirow[b]{3}{*}{$x^{2 c}$} & \multirow[b]{3}{*}{$P$ value } \\
\hline & \multicolumn{2}{|c|}{ Paint + paint } & \multicolumn{2}{|c|}{$\begin{array}{l}\text { Paint + traditional } \\
\text { insecticide }\end{array}$} & \multicolumn{2}{|c|}{$\begin{array}{l}\text { Fumigant } \\
\text { canister + } \\
\text { traditional } \\
\text { insecticide }\end{array}$} & \multicolumn{2}{|c|}{$\begin{array}{c}\text { Traditional } \\
\text { insecticide + } \\
\text { traditional } \\
\text { insecticide }\end{array}$} & & \\
\hline & No. & $\%$ & No. & $\%$ & No. & $\%$ & No. & $\%$ & & \\
\hline Yes & 47 & 28.8 & 33 & 34.4 & 54 & 41.9 & 247 & 93.9 & 232.7 & $<0.0001$ \\
\hline No & 116 & 71.2 & 63 & 65.6 & 75 & 58.1 & 16 & 6.1 & & \\
\hline
\end{tabular}

a Treatment combinations are indicated for treatment inside the house and near the house, respectively.
${ }^{\mathrm{b}} n=651$.

${ }^{c}$ Kruskal-Wallis test. 
ond application of that same treatment, there was a strong preference for having their homes treated inside with the traditional insecticide (Table 5). Those persons said they believed the traditional insecticide would be more effective in killing the triatomines and other domestic pests, or that their neighbors had made that recommendation. (Excluded from Table 5 are the persons from the traditional insecticide + traditional insecticide group who indicated they did not want a second application of the same treatment (16 out of 263 persons, or $6.1 \%$ )).

Community-level focus groups. Through the focus groups it was possible to find out more in depth concerning the reasons for the low acceptability of the new tools. The majority of the people considered that the insecticidal paint was ineffective in eliminating triatomines. The focus group members made such comments as "I did not see any killing effect" and "It did not kill the triatomines and domestic pests." Other persons said the paint smelled horrible and was responsible for headaches and vomiting. Asked about what they had thought when the various treatments were initially applied, many persons said they had preferred the insecticidal paint because it made the houses look very colorful and attractive, creating feelings of pride. For this reason the community members nicknamed the paint "Shiny." The

TABLE 5. Preferred second triatomine control treatment for persons who wanted an alternative to the first treatment, Honduras, 1991-1992

\begin{tabular}{|c|c|c|c|c|c|c|}
\hline \multirow{3}{*}{$\begin{array}{l}\text { Preferred alternative for } \\
\text { inside the house }{ }^{b}\end{array}$} & \multicolumn{6}{|c|}{ Initial triatomine control measure ${ }^{a}$} \\
\hline & \multicolumn{2}{|c|}{ Paint + paint } & \multicolumn{2}{|c|}{$\begin{array}{l}\text { Paint + traditional } \\
\text { insecticide }\end{array}$} & \multicolumn{2}{|c|}{$\begin{array}{c}\text { Fumigant } \\
\text { canister + } \\
\text { traditional } \\
\text { insecticide }\end{array}$} \\
\hline & No. & $\%$ & No. & $\%$ & No. & $\%$ \\
\hline Insecticidal paint & 1 & 0.8 & 0 & 0.0 & 0 & 0.0 \\
\hline Fumigant canister & 0 & 0.0 & 1 & 1.6 & 0 & 0.0 \\
\hline Traditional insecticide & 84 & 72.5 & 46 & 73.0 & 48 & 64.0 \\
\hline Some other insecticide & 31 & 26.7 & 16 & 25.4 & 27 & 36.0 \\
\hline
\end{tabular}

Concerning the fumigant canisters, the field operators mentioned the lack of effectiveness against triatomines and domestic pests and the occasional unexpected explosion of a canister when its fuse was lit. However, the transportation and application were very simple, and the productivity of houses completed per day was increased.

Concerning the traditional insecticide, the field operators mentioned no difficulties relating to transportation and application, and they said that using the traditional insecticide inside the homes was more effective than the other approaches.

The majority of the people who received the fumigant canisters mentioned that they were not effective in eliminating triatomines and pest insects, with a perceived effect of only one week. In contrast, the traditional insecticide was considered very effective against triatomines and also against such domestic pests as cockroaches, bedbugs, fleas, and even mice.

Field operator focus group. In their focus group, the field operators mentioned a number of difficulties with the insecticidal paint. The problems included difficulty in transporting it, frequent obstruction of the sprayer pump nozzle, the need for a very careful washing of the spraying equipment after each treatment, and deterioration of their uniforms due to permanent paint stains.

\section{Adverse effects on people and domestic animals}

In general, the household members interviewed said they had not experienced major effects on their health, nor had they noticed any effects on domestic animals (Table 6). Among the group whose homes had been treated both inside and nearby with insecticidal paint, more people reported adverse effects. Out of 163 persons in that experimental group, 24 of them (14.7\%) said they had experienced such discomforts as headaches, dizziness, nausea, vomiting, weakness, and nervousness. This was statistically significant in comparison to the other groups, especially the one where fumigant canisters had been used inside the houses. Of this latter group, only 2 out of 127 respondents $(1.6 \%)$ reported side effects.

As part of the survey, household members were asked what they would do if they were to see triatomines in their homes. Slightly more than half (55.0\%) mentioned that they would trap the bugs in a bag and take them to a health inspector, and $17.2 \%$ said they would take them to a health center. Only $8.3 \%$ indicated that they would use insecticides to control the vector.

\section{DISCUSSION}

This was the first field experience in Central America testing public acceptance of the new Chagas' disease vec- 
TABLE 6. Side effects produced by the triatomine control measures in the studied population, Honduras, 1991-1992

\begin{tabular}{|c|c|c|c|c|c|}
\hline \multirow[b]{2}{*}{ Triatomine control measure ${ }^{a, b}$} & \multicolumn{2}{|c|}{ Side effects } & \multirow[b]{2}{*}{ Odds ratio } & \multirow[b]{2}{*}{$95 \%$ confidence interval } & \multirow[b]{2}{*}{$P$ value } \\
\hline & Yes & No & & & \\
\hline Paint + paint & 24 & 139 & 4.83 & $(2.07,11.56)$ & 0.00002 \\
\hline Paint + traditional insecticide & 8 & 88 & 2.55 & $(0.86,7.47)$ & 0.054 \\
\hline Fumigant canister + traditional insecticide & 2 & 127 & 0.44 & $(0.06,2.23)$ & 0.287 \\
\hline $\begin{array}{l}\text { Traditional insecticide }+ \text { traditional insecticide } \\
\text { (reference group) }\end{array}$ & 9 & 252 & 1.00 & & \\
\hline
\end{tabular}

tor control tools that had been developed by the UNDP/World Bank/ WHO Special Programme for Research and Training in Tropical Diseases. The results of this study in Honduras were different from those of trials in South America, which showed optimal results against Triatoma infestans $(17,18,31,32)$.

In Honduras, the community members and the field operators considered the traditional sprayed insecticide to be more effective than the fumigant canisters and the insecticidal paint in eliminating triatomines. Those persons believed the traditional insecticide kept the majority of the houses free from triatomines for up to one year after application, even though the manufacturer indicates the residual effect lasts only three months. In addition, the residents of the study area did not make any major structural improvements in their houses that could have prevented the colonization of triatomine vectors during the time of the study.

The authors and the vector control field supervisors checked other endemic communities in Honduras that also had applied the traditional insecticide and found that the homes in those areas also remained free of triatomines for longer than the residual period specified by the manufacturer. This was the first time that the traditional insecticide had been applied in Honduras for Chagas' disease vector control, so any application in an endemic area would have a long-lasting impact. Others investigators have made similar observations; in Venezuela, the reinfestation of houses occurred around six months after the application of fenitrothion (33).

The respondents ranked the fumigant canisters as the least effective control method. This was due to the canisters' limited ability to eliminate triatomines and prevent the reinfestation of the houses. This was to be expected, since the canisters lack any residual effect. The general consensus of the respondents in the focus groups was that one week after the canister application, the houses were reinfested.

This study indicates that fumigant canisters are not a feasible alternative for triatomine control in this region of Honduras. The apparent lack of effectiveness might have been influenced by the characteristics of the dwellings in the zone. These houses are not totally airtight, and they have many bug hiding places where the fumigant cannot reach. This is especially true for homes with thatched roofs and bahareque walls (34). Additional research should be carried out in order to determine the ideal housing structure in which to apply this tool. In Argentina favorable results have been obtained with the fumigant, and the canisters have been proposed as part of an integrated primary health care strategy (32).

For all the control measures, adverse effects among the population were minimal. However, the persons whose homes had received insecticidal paint treatment complained of more discomfort related to headaches, dizziness, nausea, vomiting, nervousness, and fatigue, all of which are mild symptoms of organophosphate intoxication. These effects were expected, because the active ingredient of the paint is malathion (17). The effects in any of the study groups on morbidity and mortality of domestic animals were insignificant.

Another key factor in the high acceptability for the traditional insecticide was the community's perception that the traditional insecticide was much more effective than the other approaches at controlling pest insects.

Due to a lack of health education about Chagas' disease transmission, the population consider the triatomine vector pernicious but not necessarily dangerous or significant. Instead, the residents equate the triatomines with such other pest insects as fleas and bedbugs, based on their nuisance value $(20,35,36)$. The community's acceptance of the traditional insecticide was based mainly on its broad lethal effect on the pest insects. Because the different study groups were randomly distributed within the communities, the families could observe the effects inside their homes and those of their neighbors and compare the effectiveness, smell, and health consequences of the various treatments.

Among the reasons mentioned for declining a potential second application of the insecticidal paint was the peeling of the paint from the treated surfaces over time and the resulting deterioration in the initially attractive appearance of the house. This experience has not been reported in other regions where the insecticidal paint has been tested. A possible explanation is that the soil in the Honduras study areas is highly alkaline and contains a 
high proportion of clay, thus decreasing the paint's adherence to the surface. This was especially true in Area A, in the municipality of Cedros.

Packaging the insecticidal paint in 5-liter plastic containers made transporting them difficult, especially when the houses were widely dispersed in mountainous regions. Due to the difficulty of getting to these houses, many of the fragile containers broke. The large size of the containers also required a great deal of physical effort by the field personnel and reduced the amount of work they could accomplish.

The obstruction of the nozzle in the paint-spraying equipment has been observed in Brazil, and is due to the latex polymerization, which occurs when the insecticide comes in contact with air (17). To clear the nozzle, it was necessary to wash the equipment after each application using small brushes with strong bristles. Though not difficult, it was a time-consuming task that reduced the productivity of the team. Even worse, it posed the problem of looking for water to clean the equipment in a region where water is scarce.

The deterioration of the uniforms because of the paint stains was yet another difficulty for the field personnel, who received only five uniforms per person per year and so regretted the loss of each one.

Because the fumigant canisters were easy to transport and apply, the field operators' productivity was increased. However, the community residents found the canisters had only limited impact on the triatomines and pest insects and no residual effect.

Field personnel found that the traditional insecticide presented few difficulties in transportation and application. However, their opinion could have been influenced by the fact that they were already familiar with the traditional insecticide since they used it regularly to control malaria. Never- theless, they agreed unanimously that the traditional insecticide used inside the houses was more effective against the triatomines and domestic pest insects than the other approaches.

Although the intervention did not have a specific educational component, there were some positive outcomes. In response to the survey question asking what they would do if they saw triatomines in their houses, $72 \%$ of the community members said they would trap the bugs and inform a health official. In contrast, in the baseline survey before the application of the treatments, $80 \%$ of the people indicated that their only measure to avoid triatomines was to wait for institutional application of insecticides (35).

\section{RECOMMENDATIONS}

On the basis of these findings we provide a series of recommendations for the manufacturers of the insecticidal paint and of the fumigant canister, and for health officials.

For the manufacturer of the insecticidal paint we suggest:

- Increasing the effectiveness of the formulation against triatomines and pest insects, by selecting another insecticide. According to our results, a good choice would be fenitrothion, and experimental field trials of it should be encouraged. In Ceará, Brazil, insecticidal paints containing fenitrothion were tested in 3000 houses. With an $83 \%$ efficacy level 24 months after application, the paints were more effective than the insecticides normally used by the vector control program (37).

- Changing the smell of the product in order to increase the acceptance by the population, and to avoid side effects produced by malathion.

- Designing a stronger container more resistant to breaking.
- Improving the paint formulation, to avoid the polymerization of the latex, prevent the spray nozzle from clogging, and reduce the time needed for application.

- Investigating the soil composition in the study area to identify what made the paint peel away from the treated surfaces.

To the manufacturer of the fumigant canister we recommend:

- Increasing the fumigant canister's effect against triatomines and pest insects.

- Improving the canister in order to prevent explosions at the time of the application.

Finally, efforts to control Chagas' disease must apply an integrated approach that incorporates insecticide application, house improvements, health education, and community participation (20-22, 34, 36). Future field trials should use this methodology in order to generate active community participation that ensures the sustainability of the interventions.

Acknowledgments. This investigation received financial support from the UNDP/World Bank/WHO Special Programme for Research and Training in Tropical Diseases under Contract ID 900596. Thanks go to the field personnel of Health Region I for their cooperation. The authors also extend their thanks for the technical assistance provided by Ramón Rosales Montoya, the field supervisor who was responsible for data gathering. The researchers also wish to thank Peter Winch, Manuel Sierra Santos, and Ramón Soto Hernández for their technical review and suggestions, and Shawnda Adams, a U.S. Peace Corps volunteer, for helping prepare the manuscript. 


\section{REFERENCES}

1. World Health Organization. Control of Chagas disease. Geneva: WHO; 1991. (WHO Technical Report Series 811).

2. World Health Organization. Tropical disease research, progress in international research 1987-1988. Ninth programme report. UNDP/ World Bank/WHO Special Programme for Research and Training in Tropical Diseases. Geneva: World Health Organization; 1989.

3. World Health Organization. Tropical diseases, progress in research, 1989-1990. Tenth programme report. UNDP/World Bank/ WHO Special Programme for Research and Training in Tropical Diseases. Geneva: World Health Organization; 1991.

4. Sousa E. La enfermedad de Chagas en América, tendencias generales, 1991. In: Cosenza H, Kroeger A, eds. Seminario-taller: enfermedades parasitarias de mayor prevalencia y transmitidas por vectores en Centroamérica. Tegucigalpa: Comunidad Económica Europea; 1992. p. 45-53.

5. Schofield CJ. Triatominae-biology and control. Bognor Regis, West Sussex, United Kingdom: Eurocommunica Publications; 1994.

6. Hayes R, Schofield CJ. Estimación de las tasas de incidencia de infecciones y parasitosis crónicas a partir de la prevalencia: la enfermedad de Chagas en América Latina. Bol Oficina Sanit Panam 1990:108;308-316.

7. World Bank. World development report 1993. Investing in health. New York: Oxford University Press; 1993.

8. World Health Organization, Special Programme for Research and Training in Tropical Diseases. Prospects for elimination: Chagas disease, leprosy, lymphatic filariasis, onchocerciasis. Geneva: WHO; 1997. (Publication TDR/GEN/97.1).

9. Ponce C. Enfermedad de Chagas en Honduras: prevalencia y control. In: Cosenza $\mathrm{H}$, Kroeger A, eds. Seminario-taller: enfermedades parasitarias de mayor prevalencia y transmitidas por vectores en Centroamérica. Tegucigalpa: Comunidad Económica Europea; 1992. p. 71-76.

10. Ponce C. Informe final del estudio de prevalencia de la enfermedad de Chagas en Honduras. Tegucigalpa: Ministerio de Salud, Laboratorio Central; 1986.

11. Sierra M. Epidemiology of chagasic heart disease in Honduras [doctoral thesis]. Boston: Harvard University, School of Public Health; 1995.

12. World Health Organization. Tropical disease research. Progress 1991-92. Eleventh programme report. UNDP/World Bank/WHO Special Programme for Research and Training in Tropical Diseases. Geneva: World Health Organization; 1993.

13. Dias JCP, Schofield CJ. The Southern Cone Initiative against Chagas disease. Adv Parasitol 1999;42:1-27.
14. World Health Organization. Andean countries initiative launched in Colombia. TDR News 1997;53:3.

15. World Health Organization. Chagas disease: Central American Initiative launched. TDR News 1998;55:6

16. Oliveira Filho AM. Development of insecticide formulations and determination of dosages and application schedules to fit specific situations. Rev Argent Microbiol 1988;20 (1 Suppl):39-48.

17. Oliveira Filho AM. New alternatives for Chagas disease control. Mem Inst Oswaldo Cruz 1984;79(Suppl):117-123.

18. World Health Organization. Tropical disease research. Progress 1995-96. Thirteenth programme report. UNDP/World Bank/WHO Special Programme for Research and Training in Tropical Diseases. Geneva: World Health Organization; 1997.

19. Wood E, Casabé N, Licastro S, Wallace G, Zerba E. Estudios sobre la seguridad en el uso del pote fumígeno insecticida CIPEIN PF-5. Acta Bioquim Clin Latinoam 1992;26(3): 355-364.

20. Schofield CJ. Control of Chagas'disease vector. Br Med Bull 1985;41:187-194.

21. Avila Montes GA, Martínez M, Ponce C, Ponce E, Rosales R, Orellana L, et al. Participación comunitaria para el control de la enfermedad de Chagas: experiencia en un área endémica de Honduras. Rev Med Hondur 1996;64:52-59.

22. Manderson L, Luzviminda V, Thomas B. Bringing the people in: Community participation and the control of tropical disease. Geneva: World Health Organization, 1992. (Resource paper for Social and Economic Research in Tropical Disease No. 1, UNDP/ World Bank/WHO Special Programme for Research and Training in Tropical Diseases).

23. Bolivia, Ministerio de Desarrollo Humano, Secretaria Nacional de Salud, Proyecto de Salud Infantil y Comunitaria. Chagas en Bolivia. El trabajo del programa piloto de control de Chagas SNS/CCH. La Paz: MDH, SNS, PSIC, Agencia Internacional de Desarrollo de los EE.UU en Bolivia P.L. 480; 1994.

24. Organización Mundial de la Salud. Protocolo estandard para el ensayo de nuevas estrategias de control de vectores de la enfermedad de Chagas. Ginebra: OMS; 1989. (Documento TDR/CHA/URU/89.3).

25. Organización Mundial de la Salud. Encuentro latinoamericano sobre sistemas de vigilancia para evaluar el impacto de los programas de control de la enfermedad de Chagas. PNUD/ Banco Mundial /OMS Programa Especial de la OMS de Investigaciones y Enseñanzas sobre Enfermedades Tropicales, Córdoba, 25-29 November 1991. (TDR/CHA/EVA/91.3).

26. Ponce C, Ponce E, Avila Montes GA, Flores M. Final report of study of interventions trials of new tools to control transmission of Chagas disease. Tegucigalpa: Ministry of Health, Central Laboratory; 1994.

27. Flores M, Ponce C, Ponce E, Avila Montes GA. Final report cost-effectiveness study SG-56 P 89.9. Tegucigalpa: Honduras Autonomous National University; 1994.

28. Ponce C, Ponce E, Flores M, Avila Montes GA Intervention trials of new tools to control transmission of Chagas disease in Honduras. Mem Inst Oswaldo Cruz 1993;88 (Supl):57-58.

29. Scrimshaw SCM, Hurtado E. Rapid assessment procedures for nutrition and primary health care. Anthropological approaches to improving programme effectiveness. Los Angeles, California: UCLA Latin American Center; 1987.

30. Zerba EN. Insecticidas-su clasificación, manufactura, usos e investigación en el país. Industria y Química 1978;270:40-45.

31. Oliveira Filho AM, Melo MTV, Figueiredo M, Santos CE, Silva EL, Días JCP, et al. Fifteen months post treatment results in the Posse-Goiás large scale field trials of insecticides and formulations for triatomines control. Ciencia e Cultura 1987;39(Suppl):817-818.

32. Paulone I Chiut R, Pérez A, Wisnivesky-Colli C, Segura E. Field research on an epidemiological surveillance alternative of Chagas' disease transmission: the primary health care (PHC) strategy in rural areas. Rev Argent Microbiol 1988;20(1 Suppl):103-105.

33. Williams J, Tonn R, Sánchez B, Ortega R, Castillo C. Comparación de tres diferentes tipos de equipos para aplicar insecticidas en el control de los vectores de la enfermedad de Chagas con OMS-0043. Bol Dir Malariol Saneam Amb 1979;XIX(2):66-72.

34. García Zapata MA, Marsden P. Enfermedad de Chagas: control y vigilancia con insecticidas y participación comunitaria en Mambaí, Goiás, Brasil. Bol Oficina Sanit Panam 1994:116(2):97-110.

35. Ávila Montes GA, Martínez M, Ponce C, Ponce E, Hernández R. La enfermedad de Chagas en la zona central de Honduras: conocimientos, creencias y prácticas. Rev Panam Salud Pública 1998;3(3):158-163.

36. Renshaw J, Rivas D. A community development approach to Chagas' disease: the Sucre health project, Bolivia. Health Policy and Planning 1991;6:244-253.

37. Oliveira Filho AM. Recent advances in the use of slow release insecticide formulations against triatomines. Rev Soc Bras Med Trop 1995;28(SIII);74-78.

Manuscript received on 2 December 1998. Revised version accepted for publication on 1 June 1999. 
RESUMEN Este estudio analizó la aceptación por la comunidad de dos nuevas técnicas de control de los vectores de la enfermedad de Chagas: la pintura insecticida y los botes de fumigación. Ambas fueron comparadas con la tradicional pulverización con fenitro-

Pintura insecticida y botes de fumigación para el control de la enfermedad de Chagas: aceptación por la comunidad en Honduras tión. Entre agosto y noviembre de 1992, un año después de la aplicación inicial de los tratamientos, se realizó en una zona endémica del centro de Honduras un estudio experimental de campo para determinar la aceptación de las nuevas técnicas por parte de la población cuyas casas fueron tratadas y por parte del personal que aplicó los tratamientos. El tamaño de la muestra se calculó de acuerdo con un protocolo uniforme aplicado en seis países de América Latina. Se encuestaron 651 cabezas de familia de 15 comunidades rurales y se utilizaron grupos de enfoque para obtener información sobre los motivos que llevaron a los participantes a aceptar o rechazar los tratamientos utilizados; en estos grupos, además de los cabezas de familia, también participaron los trabajadores de campo que aplicaron los tratamientos. Los resultados obtenidos revelaron que la pintura insecticida tenía un bajo nivel de aceptación por la comunidad (28,2\%); a los trabajadores les gustaba muy poco por los problemas relacionados con su transporte, aplicación, olor desagradable y muy baja efectividad frente a los triatominos y otros insectos. El insecticida tradicional fue más aceptable tanto para la comunidad $(93,9 \%)$ como para los trabajadores, sobre todo por su potente efecto frente a los triatominos y otros insectos. Para incrementar la aceptación de la pintura insecticida sería necesario hacer más fácil su transporte y aplicación e incrementar su efectividad. Debido a su muy baja efectividad, los botes de fumigación no representaron una alternativa aceptable para el control de los triatominos. Una iniciativa de educación pública debería ser un componente de cualquier nuevo método de control que se desarrolle. 